\title{
QUANTUM PHYSICS AND CONSCIOUSNESS: A (STRONG) DEFENSE OF PANPSYCHISM
}

\author{
Carlos Eduardo Maldonado
}

\begin{abstract}
Probably the crux of quantum science is the relationship between consciousness and reality. The name for that relation is varied, and points out to a most fundamental problem, namely the possibility to overcome dualism. In science and philosophy at large, determinism and reductionism have already been tackled, if not superseded. The trouble though remains with dualism. This paper argues in favor of a radical relationship between reality and consciousness based on quantum theory. Such a relation is panpsychism, which can be translated and grasped in various other forms. The arguments are provided and some conclusions are drawn.
\end{abstract}

KeYwords: Transcendence. Immanence. Panpsychism. Quantum mechanics. Non-algorithmic information processing.

\section{INTRODUCTION}

The implicit assumption about the relationship between reality and consciousness has been a long history of transcendence, namely, the fact that consciousness transcends the immediate reality, or should transcend reality and the world; in other words, consciousness transcends itself in order to find itself in reality - whatever that means. There is an "ultimate" reality beyond appearances where consciousness is to find and realize itself. Before the transcendence is achieved, it is traditionally argued, consciousness is just an epiphenomenon. In other words, it can only witness the world and the universe without truly acting upon them (ROSENBLUM; KLUTTER, 2010).

Transcendentalism is perhaps the strongest defense of dualism - say, between res extensa and res cogitans. In everyday terms, a consciousness that is

1 Full Professor, School of Medicine, Universidad El Bosque, Bogotá - Colombia. E-mail: maldonadocarlos@unbosque.edu.co

http://dx.doi.org/10.1590/0101-3173.2018.v41esp.07.p101

\section{(i)}


not able to "transcend" is as if it had never existed. Transcendentalism entails a sense that the everyday world (the life world - Lebenswelt) lacks a deep sense of meaning and significance, and consciousness (= existence) is condemned to a sort of doomsday argument beyond which a real reality is to be found. By and large, transcendence has been the dominant worldview along the history of the western civilization.

According to the main tradition of philosophy, science, and culture, consciousness is an epiphenomenon. As Hegel once put it, consciousness arrives late to the state of the world, very much as Minerva's owl. The question then is, does consciousness or the mind act on the world, or does it just produce explanations while striving to understand what is going on in the world? The core of the problem relates the very essence of science, philosophy and the arts.

Science, philosophy and culture seem never to have been at odds with such a view - at least not until quantum physics arrived. Then the entire situation shifted radically. The crux is that undoubtedly quantum theory is the best theory about reality, i.e. the world, and the universe. The trouble is that it is presumably an incomplete theory.

The implication that consciousness or the mind is epiphenomenal is the burden of the history of science and philosophy or, in other words, the burden of the classical view of reality in the western world. To be sure, the classical view of the world is binary or dualistic.

The fancy name given to consciousness as an epiphenomenon is "emergent", namely, consciousness is an emergent property of - the brain. In other words, consciousness is not substantial - in any sense of the word. A long discussion has been taking place within either from the philosophy of mind, from physics, cosmology, philosophy or religion and theology (PENROSE et al., 2011; BARROW et al., 2005; DAVIES; GREGERSEN, 2010). Briefly, the question concerns the very essence of life in the universe (SMOLIN, 1998). Life is just a sort of fanciness in the economy of the universe, whence rare and strange (if not weird).

In this paper I will argue in favor of panpsychism, which is the thesis that claims that consciousness is not just an emergent feature of the universe, but rather that the universe itself is conscious (GRIBBIN, 1995). Thus, consciousness is innate to the universe as such. The arguments that support the claim just stated are the following: first, a short state-of-the-art 
survey of the main arguments in favor of panpsychism, the authors, and their perspectives is presented. Secondly, it will be shown that quantum science allows for an immanent (as opposed to transcendent) view of the world and reality and what this entails. The third argument demonstrates that there are levels of reality and hence also levels of consciousness. These various levels are different forms of processing information (VEDRAL, 2010). The fourth argument is a reappraisal of panpsychism that roots in an interpretation of quantum mechanics. At the end some conclusions are drawn.

All in all, it should be clear from the outset that the discussion of the universe and consciousness (or life) is not just a matter of a worldview. Instead, it is a matter of freedom, namely, the fight against determinism and making room for freedom and openness.

\section{A BRIEF STATE-OF-THE-ART ABOUT PANPSYCHISM AND THE ROAD TO QUANTUM SCIENCE}

The following lines are aimed at succinctly depicting the path that leads to the encounter of quantum theory with the problem about panpsychism, i.e. consciousness or life in the framework of reality. Afterwards the interplay between quantum science and the question about the role of life or consciousness will be briefly depicted.

Quantum theory, i.e. quantum science arises as probably the strongest denial of mechanism and determinism. The first seeds are to be found in the double-slit experiment by Young in 1803, but the crux lies in the various interpretations of that experiment. As it is known, the formalization of those interpretations led to quantum mechanics, developed early on by M. Born, W. Heisenberg, and E. Schrödinger, mainly. Briefly said, quantum mechanics consists of a very sophisticated mathematics aimed at explaining the "weird" (= counterintuitive) quantum behaviors and phenomena. Roughly said, quantum mechanics consists of three basic elements, namely indeterminacy, complementarity, and superposition - generally cited as "first principles".

The important aspect of quantum physics related to consciousness studies is to be found in the so-called measurement problem. As Jordan (1934) once put it, the act of observation both creates and modifies the observed object. Based on this, Bohr developed the standard view of quantum physics known as the Copenhagen Interpretation. This interpretation was vigorously 
opposed by Einstein. Each position was supported by other leading physicists. Bohr was supported by Heisenberg and Dirac, whereas Einstein was followed by Born and Pauli, among others. Schrödinger as well as de Broglie had rather skeptical standpoints in regard to any of the extreme positions.

The discussion between determinism (Einstein) and indeterminism (Bohr) was never solved at the moment due to extra-scientific events: the triumph of Nazism in Germany and the irruption of War World II. Later on, the discussion expanded in new directions due to the new theories of Bohm and Bell (GILDER, 2009). As a consequence, the dispute between both thesis - indeterminism and determinism - found a surprising answer. The Bell theorem and the Bell inequality led to the discovery of quantum entanglement (KAFATOS, 1999). Entanglement opened the door to teleportation (ZEILINGER, 2010), and quantum information theories (ZUREK, 1991; LLOYD, 2006).

Along the path of quantum theory, Aspect's experiment (Aspect et al., 1982) and implications of the Zeno effect (ORTOLI; PHARABOD, 2006; ROVELLI, 2015) have demonstrated that the measurement problem is inescapable and very real, and that quantum entanglement seems to be the best resolution of the Einstein-Bohr debate. Quantum entities exist on their own albeit in an entangled relationship in which the individuality of each entity is surpassed or overcome in favor of a non-local interplay.

To be sure, not many authors face the trouble about life or consciousness vis-à-vis reality or the universe. The role of life or consciousness not usually questioned. Even fewer are the authors that to some extent have related panpsychism straightforwardly to quantum physics. Table 1 presents the authors and their claims vis-à-vis this issue.

Table 1: Authors and claims about panpsychism in the framework of quantum science

\begin{tabular}{|l|l|l|}
\hline M. Kafatos and R. Nadeau & $\begin{array}{l}\text { Their understanding of } \\
\text { quantum science tends in } \\
\text { some aspects to be fluffy }\end{array}$ & $\begin{array}{l}\text { The conscious universe } \\
(1990)\end{array}$ \\
\hline H. P. Stapp & $\begin{array}{l}\text { A leading figure in } \\
\text { quantum physics, deals } \\
\text { with panpsychism rather } \\
\text { moderately }\end{array}$ & $\begin{array}{l}\text { Mind, matter, and } \\
\text { quantum mechanics (1993) }\end{array}$ \\
\hline
\end{tabular}




\begin{tabular}{|l|l|l|}
\hline J. Gribbin & $\begin{array}{l}\text { A most conspicuous } \\
\text { author in quantum } \\
\text { physics, defends soft } \\
\text { panpsychism }\end{array}$ & In beginning (1995) \\
\hline S. Kauffman & $\begin{array}{l}\text { Very good understanding } \\
\text { of quantum physics. } \\
\text { Defends panpsychism } \\
\text { openly, although not as } \\
\text { firmly as it could be }\end{array}$ & \begin{tabular}{l} 
(1999) \\
\hline
\end{tabular} \\
\hline
\end{tabular}

Source: Own elaboration

A remark is to be made here. Undoubtedly the most critical voice against determinism and against the algorithmic approach to consciousness is R. Penrose (1989; 1994). However, Penrose never goes as far as stepping all the way into the waters of panpsychism though he has spoken for the possibility of panprotopsychism, in which elements of the universe have the potential for experience.

Entanglement is thus the circumstance that allows overcoming the isolation of individual entities or systems via shared non-local, instantaneous interactions. The Bell inequality (BELL, 2004) is one of the most fundamental achievements of quantum science.

To be sure, basic dualism appears to have been overcome on the side of consciousness by authors as R. Penrose. The argument is that the mind is non-algorithmic. This entails, inversely that the basic structure of physical reality is algorithmic. I shall question this assumption here. Penrose's take on the non-algorithmicity of consciousness is not the only way. Arising from complexity science, the claim has been made that living beings are themselves not algorithmic (MALDONADO; GÓMEZ-CRUZ, 2015). In other words, they process information non-algorithmically (MALDONADO, 2017).

Furthermore, Kauffman (2016) brings the discussion about panpsychism back to Spinoza. Surprisingly, Spinoza's god is the same one Einstein agrees with, namely natura naturans and natura naturata - in other words, not a creating God external to its creation, but an immanent god who is the creation, as in pantheism. However, the truth is that pantheism can be traced back at least to the ancient Greeks when all were pagans. Pantheism means that there is either no supernatural all-powerful god (or goddess) since god is nature, or there are a plurality of gods that are intrinsic to the creatures 
and forces of nature. Panpsychism only means that consciousness is ubiquitous in nature, with or without gods.

The Greeks coined the term hylozoism meaning that matter (byle) is alive. So paganism at least suggests that all things are pervaded by life, consciousness, and multiple deities. Thus, panpsychism corresponds to a clear Weltanschauung, i.e., a world with a plurality of gods, that, like humans, are subject to passions, and none can escape the destiny written by the Moirai: Clotho, Lachesis, and Atropos - just as in the ancient Greek myths ${ }^{2}$. Figure 1 summarizes the various views of panpsychism.

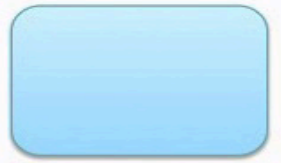

Pantheism

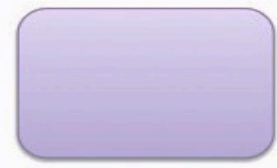

Hylozoism

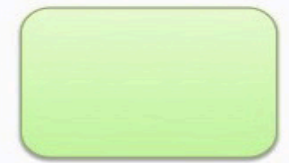

Biocentrism

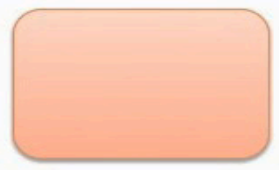

Panpsychism

Figure 1: Four shades of one and the same problem

Panpsychism can be adequately grasped: a) as biocentrism, i.e., the idea that life is the center of the universe, or also that the universe is a living organism; b) as pantheism, that is the idea that every single entity in the world is alive; c) as hylozoism, in other words the belief that matter is animated. It is my contention here that panpsychism is the title that encompasses the other three concepts in contemporary philosophy. In the fourth section bellow, I shall come back to better explaining Figure 1 .

\footnotetext{
${ }^{2}$ A myth does not mean anything irrational, over against the logos, as it has been often claimed. Literally a myth is a story (or a song story), whereas as a logical statement is a based on propositional language: $\mathrm{S}$ is $\mathrm{P}$.
} 
In any case, it should be clear that panpsychism is the name of a thesis that simultaneously transverses cosmology, consciousness, nature and culture.

\section{QUANTUM SCIENCE AND IMMANENCE}

Observation both creates and modifies reality. This is the famous problem of measurement in quantum physics. Such a problem was mathematically formalized as quantum mechanics. The trouble, though, is that along history, numerous interpretations of that mathematical formalism have arisen.

Indeed, quantum mechanics allows for over fifteen different interpretations - many of them totally incongruent with the others (see, for instance, the Wikipedia entry on "interpretations of quantum theory"). The many interpretations of quantum mechanism are to be seen a sign of the importance and vitality of the core questions implicated therein. Due to reasons of space, I shall omit discussion of the panorama of the different interpretations. Not all concern themselves with the role of consciousness or conscious observation in quantum phenomena; however, they all are intrinsically pervaded by the role of consciousness and life vis-à-vis the economy of the universe, so to speak. The crux of the matter is conscious observation.

Transcendence or transcendentalism is likely the wrong way to explain quantum quandaries, even though, as religion, it has been the dominant worldview in the history of the western world. Quantum physics hints at the opposite approach to the issue, namely immanence, i.e. the universe itself is mindful.

We just do not encounter reality "out there". This is exactly what makes of consciousness an epiphenomenon in the context of Physics. Instead, we have an experience of reality that is open-ended, unceasingly - that is exactly the story of evolution. We do experience reality in a manifold of ways, but all of those ways are still modes of experience. There is only experience, but experience may finally be the subjective side of what we have otherwise named quantum entanglement.

Living beings really do not go out of themselves in order to experience nature and reality. On the contrary, they are constantly experiencing an universe in the process of becoming. The complexity of life and the world 
consists exactly in the fact that there are only open systems - namely open to matter, energy and information. Nature at large is not a realm external and different from living beings - that is, consciousness or life. Quite on the contrary, nature and the universe may be the ways in which living beings experience themselves, their history, their environment and habitat. The universe and reality are immanent unfolding realities to life and consciousness.

Surprisingly, immanence has been a minor perspective in the history of science, philosophy and culture; it can be stated also as an alternative worldview. Table 2 presents some of the most important authors that have defended immanence.

Table 2: Important authors that claimed in favor of immanence, not transcendence

\begin{tabular}{|c|c|c|}
\hline Kant & $\begin{array}{l}\text { Kant's philosophy sets the } \\
\text { ground for an immanent } \\
\text { understanding of reality } \\
\text { in modern philosophy. } \\
\text { The world and reality } \\
\text { are experienced and not } \\
\text { encountered by the subject }\end{array}$ & $\begin{array}{l}\text { Critique of pure reason } \\
\text { (1999) }\end{array}$ \\
\hline Husserl & $\begin{array}{l}\text { Husserl has an immanent } \\
\text { view of philosophy } \\
\text { particularly in this } \\
\text { text. Besides this book, } \\
\text { Husserl's philosophy is } \\
\text { clearly transcendental. } \\
\text { That is what intentionality } \\
\text { exactly consists of. }\end{array}$ & $\begin{array}{l}\text { Vorlesungen zur } \\
\text { Phänomenolgie des inneren } \\
\text { Zeitbewussteins (2000) }\end{array}$ \\
\hline Deleuze & $\begin{array}{l}\text { Deleuze argues in favor } \\
\text { of an immanent view of } \\
\text { reality and is probably } \\
\text { the leading author in } \\
\text { contemporary philosophy } \\
\text { about immanence }\end{array}$ & $\begin{array}{l}\text { Pericles and Verdi (1988); } \\
\text { Thousand plateaus (1980) } \\
\text { (together with F. Guattari) }\end{array}$ \\
\hline
\end{tabular}

Source: own elaboration

Table 2 presents the landmarks of immanence in the history of philosophy or science. However, some other names could be included. Notwithstanding, there is barely any mention in the literature about the 
relationship between quantum physics and immanence in the three authors considered in Table 2. It should be clear that the authors included in Table 2 never deal with quantum theory, either because of historical reasons or also because they are not concerned with the theory.

It is my contention that immanence does take place in the corpus of quantum science via or thanks to or based on entanglement. An entangled state is an intertwining that is more than the parts entangled. Succinctly, it can be safely said that, at the end of the day, quantum physics consists of three intrinsically related layers: quantum mechanics, quantum waves, and entanglement. Entanglement can be understood as the strongest argument against mechanism and determinism, for it supersedes individuality.

In the literature there is nearly no reference to the relationship between quantum physics and immanence, except for Thiele (2016), who is not rigorous in his understanding. Some floppy assessments are introduced here and there without any further justification. Indeed, the rationale for transcendence is the assumption of overcoming individuality. A singular entity exists to some extent on its own, but is entirely incomplete; so it seeks to transcend itself - to realize itself in a different stance. In other words, transcendence is a fulfillment of individuality onto a realm that is extrinsic to the existence of the entity considered.

Bell's inequality has shown that quantum entanglement does take place over large distances (ASPECT et al., 1982; YIN et al., 2017), and for more than between two entities. Quantum entanglement has been experimentally proven among three or four entities, originally by Fuchs (2003). Entanglement is an immanent relationship, i.e. an intrinsic, deeply interwoven interplay. Yet, an interpretation of entanglement as immanence has never been openly set out in the literature.

Quantum science can be said to be a science of immanence, over against the entire history of science. Reality and consciousness are closely and deeply entangled stances, so they do not exist isolated. The measurement problem, or also the act of observation is grasped and explained differently once entanglement is incorporated in the corpus of science. This is probably the most fundamental achievement of quantum science (STAPP, 1993). In other words, the universe cannot be explained in the absence of life; moreover, the universe and life are deeply intertwined. To be sure, quantum entanglement is a much more robust relationship than, say, correlation. 
An immanent view of the world and reality means that consciousness cannot be merely an epiphenomenon and must have (serious) consequences in shaping the reality process. This claim is not to be taken as indicating consciousness creates reality. Instead, consciousness is in an entangled state with the physical universe, so much so that neither can be explained without the other. It is this relationship that gives meaning to any further phenomenon - the entangled relationship between subjective experience (i.e. consciousness) and the physical universe is life.

Generally speaking, quantum entanglement brings out a networked view of reality and the universe in which there is no center no matter what, for what is truly relevant is the clustered relationship that acts as a map, as a graph or hyper-graph, and in which the entire web is much more meaningful than a single clear-cut part of the map or web. Properly speaking, the part highlighted is an abstraction and most probably a mistake vis-à-vis the global view gained or obtained. From this perspective, there are no hierarchies in the universe.

The focus or emphasis on individual entities constitutes a serious hurdle for getting maps, networks or graphs. Individuality, moreover, entails centrality and hierarchy. In contrast, a quantum view of reality and the universe is an alternative to hierarchical comprehensions of reality, or also to individualized explanations of the world.

Immanence can said to be the philosophy of quantum theory - when "philosophy" is taken in the broadest sense meaning logics or basis. Be that as it may be, the issue can be stated in different ways, as it has been, indeed, namely as the relationship between mind and matter, or between quantum physics and consciousness or also between mind and brain (or consciousness and brain) (SONG, 2018). In any case, entanglement allows for an intrinsically intertwined relation in which neither one extreme nor the other is fundamental or self-consistent. Matter, the universe, the brain, for instance, are subjects of experience, very much as the mind, consciousness or life are experiences themselves - hence they appear as having a rationale in one time, place or circumstance, and a different meaning and significance according to the way and depth of our experiences.

Briefly said, quantum theory modifies radically the very conception and experience of matter, the world and the universe - as any other science, theory or philosophy has ever done. In other words, the universe experiences 
itself as a living organism via consciousness or intelligence, but intelligence or consciousness exists in a manifold ways. This leads us on to the next section.

\section{LEVELS OF CONSCIOUSNESS AND REALITY AND THE PROCESSING OF INFORMATION}

Consciousness can be explained not so much in ontological terms ("it is this or that"), but in terms of what it does. I shall claim that consciousness processes information, and it processes information in non-algorithmic ways. Processing information is an act, and action, an experience - a process.

Strikingly but meaningfully, the human mind can understand what cannot be done algorithmically. Moreover, the mind is ultimately not algorithmic (KAUFFMAN, 2016; MALDONADO; GÓMEZ-CRUZ, 2017). Yet, vice versa, the universe, nature or the world are constantly looking (or caring) about itself and its environment - if one considers the responsive nature of Earth's environment (LOVELOCK, 2000). The difference between consciousness and the universe is a difference of time scales - whence the differences between the types of information processing.

The universe can be considered a living being; in this case, nature is alive. This means that there is no life in nature, as if nature (= the Earth) was a container of living beings. This is the crux of the argument. The argument that supports the life of nature can be traced back to geomorphology (THOMPSON, 1992), geochemistry (VERNADSKY, 1997), and the Earths' physiology (LOVELOCK, 2000). However, within the framework of quantum science a clear support can be found in Kauffman (2016).

A different approach to the issue can be brought out in the following terms: information processing, learning, memory, decision making, choice, predictive modeling, associative memory, sensory integration and control of behavior are all aspects of biological intelligence (BALUSKA et al., 2006). Still, consciousness and the mind pervade reality. Biology, thus, encompasses much more than the study of living beings, so much so that quantum science does not follow common sense. Consciousness and reality are closely entangled and the processing of information is the way in which the entanglement takes place.

It should be stressed that consciousness - or mind - is not a singular human feature. Consciousness has been rightly associated with living beings at large, and not only, and not mainly, the great mammals - for it comes all 
the way down into the lowest levels of nature. Yet, within the framework of quantum science, consciousness is a feature that arises already from the very particles and waves (CONWAY; KOCHEN, 2006) that constitute it. To be sure, the strong free will theorem is certainly a strong defence for anthropocentric worldviews. It shows that particles and waves behave exactly in the way in which subjects of behavioral sciences behave; as a consequence, they are free in the strongest sense of the word; that is, they read the environment and act upon it by choice, and are not just unconscious responses to a stimulus. Free agency pervades nature (SOLÉ; GOODWIN, 2000).

From the human point of view, as people grow up and learn new ways of processing information are developed (PENROSE; HAMEROFF, 2011). The very development of information processing occurs according to the evolution - of the individuals or the species. The nonlinearity of life means that living beings gain information - although not necessarily memory. Living is thus the process by which we gain information, and this is the very condition for learning. Any system that is capable of learning can adapt to the environment. Quantum entanglement is the process by which new information is gained and processed at the same time.

All in all, the reality of the world depends on our observation. It is the theory what determines what we can see (Einstein). The observation is conscious, and consciousness transforms data into information, and information into knowledge. The physical reality of an object depends on how we choose to observe it (GILDER, 2009). Shortly said, we create our own reality.

\section{Panpsychism, ReConsidered}

Panpsychism adopts a twofold way, thus: on the one side, it is about the role of consciousness in reality, whereas, on the other side, it deals with life and its place in the economy of the universe. The second assumption is known as the question about the anthropic principle (BARROW; TIPLER, 1989). The first take is the most "orthodox" within the framework of quantum physics.

Here I do not argue in favor of the anthropic cosmological principle, in neither its weak nor its strong version. The biases have been severely criticized 
and the consequences lead always to some form of religion or pseudo-science (WARD; BROWNLEE, 2000).

Panpsychism turns out to be nearly identical to hylozoism and pantheism, and biocentrism ${ }^{3}$. What appears in Figure 1 above as four different stances is after all a united framework. The name of such a framework is "life". In simple words, consciousness can be here grasped as life.

Classically stated, the question is whether consciousness affects reality by the act of observation. More radically, the question then becomes how life affects the universe by being and becoming. Quantum theory is after all, it seems, about the role of freedom in the universe.

The universe is conscious and alive, simply because consciousness and reality are entangled, which therefore means that one does not exist without the other. Quantum science shows that quantum phenomena rely on superpositions - in other words, on possibilities. In the framework of the quantum world, possibilities are real, i.e. ontologically real.

As S. Kauffman (2016) puts it, life is a physical property of the universe itself, very much as temperature, mass, energy, gravity, etc. Life and consciousness are not even emergent phenomena, but ever-present aspects of reality. In the same way, consciousness is a physical property of the brain, just very much like synapsis, the system of glands, or electro-chemical impulses.

The question then about how consciousness or the mind arises from the brain or how life appears in the universe are wrong questions, for they are posed in terms of causality and its variants - emergentism (POPPER, 1995), and superseded relations (CHALMERS, 1996). If freedom is to make any sense at all in the universe, then consciousness is not an epiphenomenon, and life cannot be understood in terms of transcendence. Quantum science sets out the ground for freedom hereafter.

\section{Conclusions}

This paper argues for a strong defense of panpsychism. However, by all means mysticism must be discarded here, even though panpsychism

\footnotetext{
${ }^{3}$ Biocentrism has been claimed by Lanza (2009). Here I take some distance of Lanza's arguments, mainly because of some metaphysical undesirable arguments. The very fact that D. Chopra has welcome Lanza's book is already a sufficient reason to be suspicious about its scientific rigor. Here I just keep the very concept without incurring into arguments like Lanza does.
} 
has been associated with mysticism. The claim here has not never been that consciousness creates reality. Rather, the contention of this paper is that reality is a living system - whence a conscious stance. Yet, reality as such (überhaupt) does not really exist. There are levels of reality - hence also levels of consciousness.

The classical understanding of consciousness conceives of it as just witnessing the world. The world happens, and consciousness tries, as hard as possible, to grasp what has happened or what is going on "out there". Quantum theory, on the contrary, allows understanding that consciousness acts upon reality - in acausal ways. To be sure, causality is not the only way in which action happens in the universe. It is not even the main way; it is just the way the classical science of western civilization says it happens.

In a world in which consciousness is a mere witness freedom does not exist, it is an illusion. Consciousness is then a mere product of the objective world. In such a reality predestination, determinism and fatalism naturally predominate - very much as, for instance, the Laplace's demon. However, if one assumes that consciousness and free will do not emerge with life, but as part of the universe, whence panpsychism is entirely justified, freedom is possible - moreover and paradoxically, freedom is unavoidable, inescapable. The universe or nature is the very realm of freedom, very much as consciousness is the unceasing experience of freedom.

It should be highlighted that freedom coincides with randomness - a most radical openness, which goes against the notion that randomness is chaotic. Quantum mechanics tells us about the ultimate randomness of nature in more than fifteen different interpretations. Dealing with randomness and life are two sides of one and the same token. Nonetheless, one should not conclude that life is totally random; instead, randomness pervades life to some extent.

Panpsychism disallows any form of determinism. It is freedom, after all - freewill, if you wish - that is finally at stake in this discussion. Life, it is claimed here, is about gaining degrees of freedom, and enhancing, enlarging or deepening the degrees of freedom already attained. As it is well known, the complexity of a system is proportional to the degrees of freedom the system has or exhibits. The more degrees of freedom a system has, the more complex it is. 
The mechanist interpretation of the world is wrong - very much as the deterministic interpretation of the world is wrong, too. Quantum science opens up the doors to a view of the world where freedom is possible - hence life is possible as well, not just an emergent property of matter.

More than fifteen different interpretations of quantum mechanics coexist, to date. The conclusion is that the many interpretations of quantum mechanics allow the present to be different. Quite another issue would be a critical appraisal of these many interpretations. This remains the subject of a different paper.

Consciousness processes information in non-algorithmic ways. If so, then quantum superpositions violate a rigid view of reality, a view that truly disenchants the world, as once Prigogine and Stengers (1988) state. Ultimately, panpsychism is grounded in, or is supported by, quantum entanglement.

Coda: Xenophanes of Colophon, the ancient Greek philosopher deserves a moment here. A paraphrase of his ideas would sound like the following: The gods for every living being are human-like; for cats, they are cat-like; for trees, the gods are tree-like, for the rocks, they are rock-like, and the like. In other words, over against the typical representation and conception of the gods, God or the Gods are not obliged to manifest themselves in one singular form - rather than in another. Obliging the gods to manifest themselves are, say, human beings is exactly idolatry.

MALDONADO, C. E. Física quântica e consciência: uma defesa (forte) do panpsiquismo. Trans/Form/Ação, Marília, v. 41, p. 101-118, 2018. Edição Especial.

Resumo: Provavelmente, o cerne da ciência quântica é a relação entre consciência e realidade. O nome dado a dessa relaçáo varia, o que aponta para um problema fundamental, a saber, a possibilidade de se superar o dualismo. Na ciência e na filosofia em geral, o determinismo e o reducionismo já foram abordados, se não superados. $\mathrm{O}$ problema permanece com o dualismo. Este artigo argumenta em favor de uma relação radical entre realidade e consciência baseada na teoria quântica: o panpsiquismo, que pode ser descrito e apreendido em várias formas. Os argumentos são fornecidos e algumas conclusões são tiradas.

Palavras-chave: Transcendência. Imanência. Panpsiquismo. Mecânica quântica. Processamento de informação não algorítmica. 


\section{REFERENCES}

ASPECT, A.; GRANGIER, P.; ROGER, G. Experimental realization of EinsteinPodolsky-Rosen-Bohm Gedankenexperiment: a new violation of Bell's inequalities. Physical Review Letters, v. 49, n. 2, p. 91-94, 1982. doi:10.1103/PhysRevLett.49.91.

BALUSKA, F.; MANCUSO, S.; VOLKMANN, D. (ed.). Communication in plants: neuronal aspects of life. Berlin: Springer, 2006.

BARROW, J. D.; TIPLER, F. J. The anthropic cosmological principle. Oxford and New York: Oxford University Press, 1989.

.; DAVIES, P. C. W.; HARPER, JR, C. L. (ed.). Science and ultimate reality. quantum theory, cosmology, and complexity. Cambridge: Cambridge University Press, 2005.

BELL, J. S. Speakable and unspeakable in quantum mechanics: collected papers on quantum mechanics. Cambridge: Cambridge University Press, 2004.

CHALMERS, D. The conscious mind: in search of a fundamental theory. Oxford: Oxford University Press, 1996.

CONWAY, J. H.; KOCHEM, S. The strong free will theorem. Foundations of Physics, v. 36, n. 10, p. 1441-1473, 2006.

DAVIES, P.; GREGERSEN, N. H. (ed.). Information and the nature of reality: from physics to metaphysics. Cambridge: Cambridge University Press, 2010.

DELEUZE, G. Pericles et Verdi: la philosophie de Francois Chatelet. Paris: Les Editions de Minuit, 1988.

.; GUATTARI, F. Capitalisme et schizophrenie 2: Mille plateau. Paris: Les Editions de Minuit, 1980.

FUCHS, C. Quantum mechanics as quantum information, mostly. Journal of Modern Optics, v. 50, n. 6/7, p. 987-1023, 2003.

GILDER, L. The age of entanglement. When quantum physics was reborn. New York: Vintage Books, 2009.

GRIBBIN, J. In the beginning: the birth of the living universe. Boston: Little Brown, 1995.

HUSSERL, E. Vorlesungen zur Phänomenolgie des inneren Zeitbewussteins. Berlin: W. de Gruyter, 2000. (Original 1928).

JORDAN, P. Über die Multiplikation quanten mechanischer Grössen II. Zeistchrift für Physik, volume 87, n. 7, p. 505-512, 1934.

KAFATOS, M. (ed.). Bell's theorem, quantum theory, and conceptions of the universe. Dordrecht: Kluwer Academic, 1999. 
KAFATOS, M.; NADEAU, R. The conscious universe: part and whole in modern physical theory. Berlin: Springer, 1990.

KANT, I. Critique of pure reason. Cambridge: Cambridge University Press, 1999. (Original 1781).

KAUFFMAN, S. At home in the universe. Oxford: Oxford University Press, 1999. . Humanity in a creative universe. Oxford: Oxford University Press, 2016.

LANZA, R. Biocentrism: how life and copnsciousness are the keys to understanding the true nature of the universe. Dallas, TX: Benbella Books, 2009.

LOVELOCK, J. Gaia: a new look at life on Earth. 3rd ed. Oxford: Oxford University Press, 2000. (Original 1979).

MALDONADO, C. E. Biological hypercomputation and degrees of freedom. In: LÓPEZ-RUIZ, R. (ed.). Complexity in biological and physical systems: bifurcations, solitons and fractals. London: IntechOpen, 2017. p. 83-93.

.; GÓMEZ-CRUZ, N. Biological hypercomputation: a new research problema in complexity theory. Complexity, v. 20, n. 4, p. 8-18, 2015.

ORTOLI, S.; PHARABOD, J.-P. El cántico de la cuántica. ¿Existe el mundo? Barcelona: Gedisa, 2006.

PENROSE, R. The emperor's new mind: concerning computers, minds, and the laws of physics. New York: Vintage, 1989.

Shadows of the mind: a search for the missing science of consciousness. Oxford: Oxford University Press, 1994.

.; HAMEROFF, S.; KAK, S. (ed.). Consciousness and the universe: quantum physics, evolution, brain \& mind. Cambridge, MA: Cosmology Science, 2011.

POPPER, K. Knowledge and the body-mind problem: in defence of interaction. London: Routledge, 1995.

PRIGOGINE, I.; STENGERS, I. Order out of chaos: man's new dialogue with nature. New York: Bantam Books, 1988.

ROSENBLUM, B.; KUTTNER, F. Quantum enigma: physics encounters consciousness. Oxford: Oxford University Press, 2010.

ROVELLI, C. La realidad no es lo que parece: la estructura elemental de las cosas. Barcelona: Tusquets, 2015.

SMOLIN, L. The life of the cosmos. New York; Oxford: Oxford University Press, 1998.

SOLÉ, R.; GOODWIN, B. Signs of life: how complexity pervades biology. New York: Basic Books, 2000.

SONG, D. Machine versus human. NeuroQuantology, v. 16, n. 10, p. 87-91, Oct. 2018. 
STAPP, H. P. Mind, matter, and quantum mechanics. Berlin: Springer, 1993.

THIELE, K. Quantum physics and/as philosophy: immanence, diffraction, and the ethics of mattering. Rhizomes: Cultural Studies in Emerging Knowledge, v. 30, 2016. doi:10.20415/rhiz/030.e04.

THOMPSON, D. W. On growth and form: the complete revised edition. New York: Dover, 1992.

VEDRAL, V. Decoding reality: the universe as quantum information. Oxford: Oxford University Press, 2010.

VERNADSKY, V. I. La biosfera. Madrid: F. Argentaria-Visor, 1997. (Original 1929).

YIN, J. et al. Satellite-based entanglement distribution over 1200 kilometers. Science, v. 356, n. 6343, p. 1140-144, Jun. 2017.

WARD, P. D.; BROWNLEE, D. Rare earth: why complex life is uncommon in the universe. Berlin: Springer, 2000.

ZEILINGER, A. Dance of the photons: from Einstein to quantum teleportation. New York: Farrar, Straus, and Giroux, 2010.

ZUREK, W. H. Decoherence and the transition from quantum to classical. Physics Today, v. 44, n. 10, p. 36-44, 1991. doi.org/10.1063/1.881293. 